\title{
Book Review: Making Sense out of Suffering, by Peter Kreeft, Cincinnati, Servant Books, 1986, 184 Pages
}

\author{
Samuel A. Nigro, MD \\ Retired psychiatrist, USA \\ sam@docnigro.com
}

When suffering, joy is hard to find, to feel, to believe. The negative sensations loom large as punishment, darkness, despair, anger, bewilderment, pain, loss of function, loss of identity, loss of self, witnessing evil, and the monotony of spiritless matter. Suffering is the constriction into less being until you understand Peter Kreeft, a favorite of mine since discovering "The Transcendental Variables of All Being" (learned from Kreeft's other works: Living the Truth and Guide to Thomas Aquinas) and which I first presented in 1993 (1).

To add to understanding suffering, I summarize: The Transcendental Variables of All Being--I call the first three the Catholic Trivium; and the last four are the Catholic Quadrivium.

1. Ens (Latin)-the being, i.e., what has existence.

2. Res (Latin) - the corporeal body or matter, i.e. the confluence of the being with matter completing it. It is the most visible dimension for those in the material world. In nature, nature rules, neurochemistry and all, on how the being manifests itself in nature. Bodies are needed to relate. They are our physical being by which men interact with all.

3. Aliquid (Latin) - the identity or form of the being, i.e. the confluence of the being with its essence-for humans, not ethnicity, not color, nor anything but humanbeingness-the total embracing of humanity for us-in a word "catholic" —all for and with all.

4. Verum (Latin)--the truth of the being, i.e. the confluence of the being with reality and not fantasy-or for us humans, the confluence with real life and not television shows, movies, magazines, newspapers or figments of imagination from oneself or others.

5. Unum (Latin) - the oneness of the being, i.e. the confluence of the being with itself and all desirability related to it: its integrated, whole entirety, including family, community, country, world, universe.

6. Bonum (Latin) - the good of the being, i.e. the confluence of the being with proper function in nature, or for mental beings, with proper choice in Natural Law (or Rational Environmentalism).

7. Bellezza ("bella") (Italian...preferred by the author to the Latin "pulchritude" for multicultural reasons) - the beauty of the being, i.e. its confluence with ascendancy or the "bringing out the best of itself and all around it. "

Because of what I learned from Kreeft before, his book on "suffering" rang true, 
Book Review: Making Sense out of Suffering, by Peter Kreeft, Cincinnati, Servant Books, 1986, 184 Pages

one, good and beautiful because the negatives intrinsic to suffering were projected into spirituality beyond material and physical misfortune. In Making Sense out of Suffering, Kreeft poignantly clears the mind, not an easy task, but comforting and intriguingly done Socrates style, another intellectual delight from the author.

The confluence of my Statimuum with Kreeft completes his efforts in my mind. The timelessness alluded so many times at Mass and in the Gospel confirms the transient transcendence which will recompress us by suffering into the Eternity of the pre-Big Bang required by contemporary physics. The Immediacy of all positives ever, will be immediate in the timeless spaceless unrestricted Act of Thinking we know as God as suffering turns into sacrifice and success.

Kreeft's Making Sense out of Suffering makes that clear as suffering becomes joy.

\section{REFERENCES}

1. Samuel A. Nigro, MD, "Male/Female Differences in Natural Law”, Society of Catholic Social Scientists, First Annual Conference, 1993.

Citation: Samuel A. Nigro, MD. “Book Review: Making Sense out of Suffering, by Peter Kreeft, Cincinnati, Servant Books, 1986, 184 Pages". American Research Journal of Pediatrics; 1(1): 10-11.

Copyright (C) Samuel A. Nigro, MD. This is an open access article distributed under the Creative Commons Attribution License, which permits unrestricted use, distribution, and reproduction in any medium, provided the original work is properly cited. 